
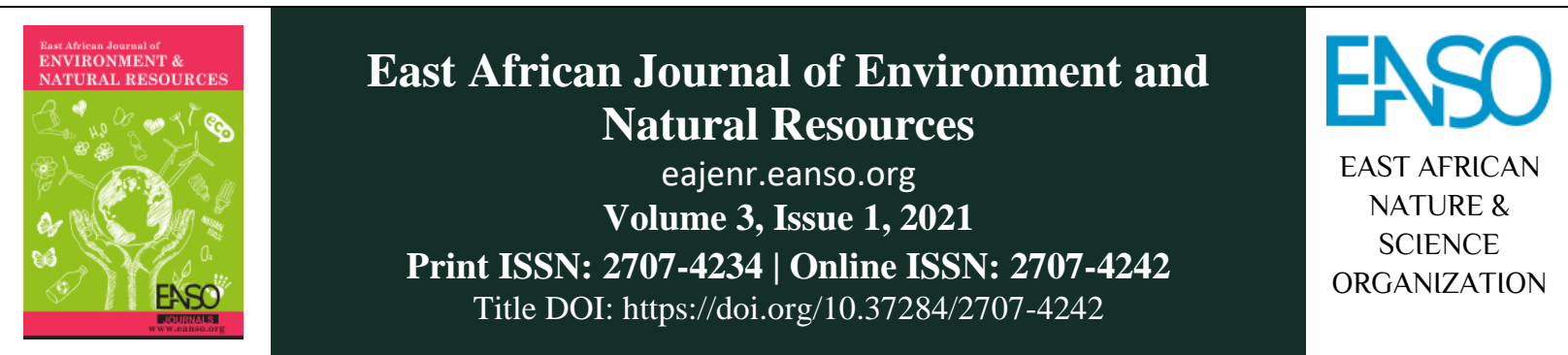

Original Article

\title{
Conserving Natural Values to Mitigate Environmental Degradation in Africa
}

\author{
Mark Omorovie Ikeke ${ }^{1 *}$ \\ ${ }^{1}$ Associate Professor, Department of Religious Studies and Philosophy, Delta State University, PMB 1, Abraka, Nigeria. \\ ${ }^{*}$ Correspondence email: Ikeke7@yahoo.com
}

Article DOI: https://doi.org/10.37284/eajenr.3.1.371

\section{Date Published: ABSTRACT}

02 August 2021 One of the gravest predicaments that Africa is suffering from is environmental degradation. Environmental degradation implies the diminishment of the beauty,

Keywords: quality, goodness, and viability of the earth and its ecosystems. Environmental degradation is precipitated by massive deforestation, desertification, drought,

Conservation, forced migration, war, food shortages, atmospheric and ocean pollution from

Nature, mining and exploitation of natural resources, human insecurities,

Values, misappropriation of environmental funds, global warming and climate change, etc. Many of these that lead to environmental degradation are anthropogenic

Mitigation, (caused by human activities and behaviours). Anthropogenic activities that

Environment, degrade the environment are often informed by systems of thoughts that see no

Degradation. intrinsic value in nature or the earth. Nature is simply seen for its utilitarian and human satisfaction purpose. The earth is simply seen as existing for human needs and purpose. Nature exists to benefits human beings. Humans are at liberty to use the earth as they desire. Other organisms have no purpose except for the good and welfare of human beings. The interests of other non-human realities do not count. This paper argues that there are values in the natural world. Beyond the benefits that nature provides for humans and the entire ecosystem, nature has intrinsic value. While humans are to make use of nature to sustain themselves like other organisms in nature, humans have a responsibility to conserve the intrinsic values in nature. The degradation and deterioration of nature takes from it religious, spiritual, aesthetic, intrinsic, ecosystemic, and other values in nature. The paper will use a critical analytic and hermeneutic method to traces various theorists on the value of nature. It will examine the situation and reality of environmental degradation. It will equally present what can be done to conserve natural values. The paper finds and concludes that conserving natural values will help to mitigate environmental degradation

78 This work is licensed under a Creative Commons Attribution 4.0 International License. 
East African Journal of Environment and Natural Resources, Volume 3, Issue 1, 2021

Article DOI: https://doi.org/10.37284/eajenr.3.1.371

\section{APA CITATION}

Ikeke, M. O. (2021). Ethical Evaluation of Environmental Stewardship in Sub-Saharan Africa. East African Journal of Environment and Natural Resources, 3(1), 78-90. https://doi.org/10.37284/eajenr .3.1.371

\section{CHICAGO CITATION}

Ikeke, Mark. Omorovie. 2021. "Ethical Evaluation of Environmental Stewardship in Sub-Saharan Africa". East African Journal of Environment and Natural Resources 3 (1), 78-90. https://doi.org/10.37284/eajenr.3.1.371

\section{HARVARD CITATION}

Ikeke, M. O. (2021) "Ethical Evaluation of Environmental Stewardship in Sub-Saharan Africa", East African Journal of Environment and Natural Resources, 3(1), pp. 78-90. doi: 10.37284/eajenr.3.1.371.

\section{IEEE CITATION}

M. O. Ikeke, "Ethical Evaluation of Environmental Stewardship in Sub-Saharan Africa”, EAJENR, vol. 3, no. 1, pp. 78-90, Aug 2021.

\section{MLA CITATION}

Ikeke, Mark. Omorovie. "Ethical Evaluation of Environmental Stewardship in Sub-Saharan Africa". East African Journal of Environment and Natural Resources, Vol. 3, no. 1, Aug 2021, pp. 78-90, doi:10.37284/eajenr.3.1.371.

\section{INTRODUCTION}

There is hardly any region in the world that is free from environmental problems. Environmental problems are inclusive of the following: depletion of the ozone layer, deforestation, acid rain, improper disposal of solid and chemical wastes, desertification, global warming, extinction of species, illegal mining, soil erosion, drought, marine and atmospheric pollutions and so forth. Africa like other regions of the world is affected negatively by these problems. Environmental problems and challenges create environmental degradation and do make the earth less habitable for human beings and other life forms.

Environmental degradation in Africa needs to be frontally tackled and combated. It needs to be overcome if Africa is to experience balanced development. The priority of this paper is to propose some key solutions to the problem of environmental degradation in Africa. While a few solutions will be presented, the key emphasis here is on conserving what the paper conceives as natural values. If natural values are conserved it will help in environmental protection. Critical analysis and hermeneutics are deployed here to carry out the concerns of the paper. The key phrases such as conserving natural values and environmental degradation will be interpreted and their imports drawn out in the paper. The paper will also break open, and interrogate the issues with the purpose of understanding. The procedure of this work after this introduction is to examine the terminologies and phrases in the title of the paper, followed by a presentation of the situation of environmental degradation in Africa. The causes and consequences of environmental degradation in Africa will also be looked at. The paper shall equally periscope some of the solutions to environmental degradation in Africa. One of the key solutions, conserving natural values will also be proposed in a moral evaluative manner. The paper ends with some concluding reflections. It is to the terminologies that the paper now turns.

\section{Terminologies}

The phrases, "conserving natural values" and "environmental degradation" need to be clarified and defined. The word, "conservation" will be the first term to be defined. Omisore and Akande (2003) citing Allaby write that managing and planning the use of resources in a wise manner to ensure their continuity in terms of value, quality, and diversity is what conservation means. Conservation, both of them note implies sustainable use, avoidance of disastrous effects, and also mitigating the environmental impact of that use. Tella (2015) writes that conservation is the protection and preservation of the environment, both natural and the built environment, from harm caused by pollution, etc. Micheals (2004) indicates that to conserve means: "to save a natural resource, such as water, through intelligent use" (p. 60). In Hook (2008), "'Conservation' is a term used to describe the deliberate efforts made by humankind to preserve animals, plants or complete habitats" (p. 55). Another definition as given by Omaka (2018) is that "conservation is the act of maintaining things 
in their natural state without any form of adulteration. It is the art of preservation" (p. 7). For Pinchot (2009) conservation implies development, "husbanding of resources for future generation," and also guaranteeing the fruitful and abundant use of resources by the present generation, waste prevention.

A value is what is of worth and considered precious by human beings. It is rational human beings that name and assigns value to things. All values are anthropogenic. Even when there is intrinsic value in a thing such as nature, it is human beings who assign value to it. Without human beings, value tough present in things will not be recognized and assigned. Natural values refer to the worth, preciousness, and good quality that human beings have seen in nature. Various values have been assigned to nature. These values, according to Holmes (1988) include life-support value, economic value, recreational value, scientific value, aesthetic value, genetic-diversity value, historical value, cultural-symbolization value, character-building value, diversity-unity value, stability and spontaneity values, dialectical value, life value, religious value, etc. As this paper has noted the human person is the valuer and the one who assigns value. The value may be there already in nature but unless it is noticed by human beings, it has no relevance to him. Holmes (1998) a founding father of environmental ethics notes that the values carried in nature are there because there is "value intrinsic in nature" and this makes humans have their own values. Holmes (1998) equally explains these in various ways. For life-support value, he says it means human life and all other life-forms depend on the ecosystem for survival and being in existence. Economic values, he says means living things use nature as a resource. Nature also has recreational value as human beings delight and enjoy it. He opines that science sees value in nature that has enabled scientific discoveries. On aesthetic value, he writes that nature enriches human experience and provides delight and pleasure. For genetic-diversity value, he enunciates that it means there is biodiversity in nature that contributes to the good of all life. Human beings, he states have also attached historical value to aspects of nature such as a forest, a landscape, a bird, totemic animals, etc. Related to the just mentioned one is that for humans, some aspects of nature symbolise various cultural meanings. People such as the Boys and Girls Scout and church groups have often in nature trained and built their character, he remarks. Nature speaks of diversity and unity he writes. Natural processes are regular, stable and also at times spontaneous.

Conserving natural values means that the abovementioned values and many other values that can be seen in nature or the environment should be safeguarded and protected. Human beings can make use of nature and nature's goods or resources within proper limits and wise use in a sustainable manner for present and future generations and also for the whole biotic good. When nature is degraded, many of these values will be lost. By conserving these natural values as something important and protecting nature from depletion, the environment is protected. If we know that when we cause environmental degradation, we destroy natural values that are essential to human survival and the wellbeing of other organisms we are likely going to conserve nature by avoiding degradation. This paper is open to the fact that nature can be used to wisely meet human needs while at the same time protecting values inhering or perceived in nature by human beings. It is also imperative to remark that there are aspects of nature that should be totally preserved from human interference.

El-Haggar (2007) defines environmental degradation as natural resources' exhaustion. Natural resources of the earth include the soil, air, land, water, mineral resources, etc. General Multilingual Environmental Thesaurus (2020) says the compromise of nature through the reduction of biodiversity or environmental health is called environmental degradation. Bellamy (2007) states that degradation is "The process of bringing down leading to end. It is the process of lowering a surface by erosion and the removal of rock waste; the general lowering of the land by erosive processes" (p. 122). For Bellamy (2007) to degrade is "to lower the standard" (p. 122). With regard to environmental degradation, it is to lower the standard and quality of the earth and its resources. It is to lessen the value of what is on earth and to deplete what the earth provides. The lowering of the value of the earth and its resources and the depletion of the resources is certainly taking place in Africa. Through natural disasters, soil erosion, deforestation, desertification, marine and 
atmospheric pollutions, etc the natural resources in Africa are being depleted and devalued. There is need for conservation in wisely managing and planning the use of the earth and its goods. This is the concern of this paper.

\section{THE SITUATION OF ENVIRONMENTAL DEGRADATION IN AFRICA}

The fact that there is environmental degradation in Africa is indisputable. Tella (2015) states that Africa is experiencing a serious decline in environmental resources especially due to population growth; ancient agricultural ways of land management being overtaken by unsustainable use, and endemic poverty ruling all over the continent. Mabogunje (1998) writing of the environmental challenges facing Sub-Saharan Africa argues that: "Sub-Saharan Africa suffers from some serious environmental problems, including deforestation, soil erosion, desertification, wetland degradation, and insect infestation. Efforts to deal with these problems, however, have been handicapped by a real failure to understand their nature and possible remedies." These problems are still prevalent in Africa today. And these problems lead to environmental degradation.

Take the issue of urbanization. There is rapid urbanization in Africa and there is tremendous growth of cities. Urbanization in Africa is often unplanned. Because it is unplanned it comes with a lot of negative consequences. All over Africa, there has been unplanned growth in cities like Lagos, Accra, Nairobi, Cairo, Johannesburg, etc. These consequences include the growth of ghettos and slums, noise pollution, increase in criminality and urban violence, etc. All these impede negatively on the environment. Omisore and Akande (2003) rightly note that rapid urbanization causes environmental problems like biodiversity loss, increase in the rate of global warming, desertification, toxic waste, water pollution, etc.

Environmental degradation in Africa is real. Mengisteab (2011) writes of the Horn of Africa that has experienced tremendous climate change which has produced rapid social and economic dislocations, famines, resource conflicts and has faced degradation as a result of these.
Another factor that can cause environmental degradation is the situation of a state without adequate governance. Without governance, it is unthinkable for there to be policies in place for environmental governance to prevent degradation. There are places in Africa bereft of the control of the state. In such places, environmental policies can hardly be implemented. There are regions in the Democratic Republic of Congo, Somalia, some areas in the Horn of Africa, some Sahel regions that are almost "stateless" or lack governance. These areas are either troubled by terrorists, kidnappers, and armed bandits or plagued by wars and violence. The environment is being degraded daily. In a place like Somalia, Adam (2001) notes that the state has collapsed and the land bedevilled by warlordism that cares nothing for environmental balance. Stremlau (2019) writes that Somalia has not been with a central government since Said Barre's fall in 1991. There can be no effective environmental policy in such a place. Adam (2001) writes that: "a restored Somali order will have to undertake immediately enforcing Somali rights and sovereignty over territorial lands and waterpreventing the plundering of coastal resources and banning the dumping of any and all forms of toxic waste" (p.225). One fact should be clear that all over Africa, areas that are difficult to govern or lack effective governance will suffer much from environmental degradation and social dislocations.

\section{Causes and Consequences of Environmental Degradation in Africa}

Many of the causes of environmental degradation in Africa are anthropogenic, meaning that they are caused by human beings whose behaviours towards nature deplete the resources and goods of the earth and its atmosphere. Omaka (2018) quotes the Secretary General of the United Nations who in 1969 opined that: "The three basic causes responsible for the deterioration of the environment are namely: accelerated population growth, increase urbanisation and an expanded and efficient new technology with their associated increase in demands for space, food and natural resources" ( $\mathrm{p}$. 19). In the place cited, Omaka (2018) declares that the five cardinal factors given by ILO-UNO as responsible for environmental degradation are: (1) population pressures, (2) technology, (3) poverty, (4) consumption patterns, and (5) energy. Omaka 
(2018) notes with regard to poverty, poor people overexploit nature and put marginal regions in their country under stress and in a place like Africa, 51\% of the poor live in marginal areas subject to environmental degradation. Though not empirically proven, as the author just mentioned notes poverty is likely to negatively affect the environment and contribute to deforestation.

One of the major causes of environmental degradation is abuse, misuse and mismanagement of solid wastes. Individuals and family members dispose of domestic wastes carelessly from their homes. They dump these wastes in roads and bushes near their residence and houses without caring about the negative effect this will have on the soil, air, and water bodies around them. Some domestic wastes like plastics, rubber, and metal or aluminium objects normally take longer to decompose. They destroy the organisms, animals, and birds in the bushes around. The foul smell from improperly disposed waste harms the air quality. The industries and factories often release chemical wastes into the environment around the industries and factories. In the bid for more profits industries often follow the easy way out. This point is corroborated by ElHaggar (2007) when he opines that: "To most investors overexploitation of natural resources is more profitable in the short run, due to cheap means of disposing of wastes, avoiding the costs of waste treatment and the excluding of social losses in cost calculations. However, in the long-run natural resources will be depleted and the losses will be irreversible." Management of waste is a serious challenge for many African cities. Nakweya (2019) cites Babajide Alo saying: "Africa seems to be lagging behind in waste management, especially chemical waste which poses risks to the health of people." Un-decomposed waste can remain in the environment for many years if not decades.

There is also the problem of materialism, consumerism, and unceasing economic growth. Many individuals and companies fail to take into consideration the limits of earth's resources. For them, the earth has unlimited resources. Shrinkhal (2019) rightly notes that "economic growth" and "mindless consumerism" harm nature. The earth does not have unlimited capacity. Meadows et al (1972) rightly opine that the earth has limited capacity and that at the rate of overpopulation and depletion of resources the prices of resources will continue to rise and the earth will continue to be depleted. Meadows, Randers and Meadows (2003) commenting at the 30 years anniversary of the report, "Limits of Growth" of the Club of Rome remarks thus: ".... we are drawing on the world's resources faster than they can be restored, and we are releasing wastes and pollutants faster than the Earth can absorb them or render them harmless. They are leading us toward global environmental and economic collapse - but there may still be time to address these problems and soften their impact."

When there is environmental degradation or natural resources are depleted, human lives and wellbeing are endangered. It can lead to the death of human beings, poverty and low quality of living. As ElHagger (2007) enunciates when there is environmental degradation the human needs for security and psychological safety are gravely affected as their sources of clean water, food, air quality are depleted. When people cannot meet their basic needs adequately even their mental health can be affected. The capacity of human beings to actively participate in socio-cultural, political and economic, and even spiritual-religious life is vitiated. El-Haggar (2007) equally supports this last point.

Another major source of environmental degradation in Africa comes from the mining and natural resource extraction industries. One major extraction industry is oil and gas companies. Take for instance a place like Nigeria's Niger Delta. For Chukwuka and Jimoh (2018) oil spillage in the Niger Delta has caused environmental pollution, degradation, impacted negatively on the germinations of seeds and development of seedlings as seeds are suffocated by oil on the soil and water bodies. Ndimele and Erondu (2018) write that:

The environmental degradation caused by oil spillage has socioeconomic impacts on the oil-producing communities. This pollution destroys the aesthetic values of water bodies. It also affects other qualities of water such as drinking, recreation, swimming, fishing, and domestic use. Eventually, there is loss of aquatic lives, which has a devastating impact on the livelihood of fisherfolk households who solely depend on fishing. Webler and Lord 
(2010) noted that humans can be affected by oil spills in three major ways: oil can affect ecological processes that cause direct harm, e.g., health impacts from eating seafood with bioaccumulated oil toxins; oil spill stressors can change intermediary processes, e.g., economic impacts on fishers caused by oil spill damage to fisheries; and stressors can directly harm humans, e.g., health impacts from breathing oil vapors. It is therefore important to restore the ecosystem, ensure conservation, and protect human health.

At the heart of the anthropogenic factors that precipitate environmental degradation is the human heart. Ayorinde and Olufemi (2003) citing R. Hudson, and E F. John et al note that: "The ecological crisis is as a result of intrinsic desire of humankind to expand and grow" (p. 66). They note that environmental crisis is as a result of wrong attitudes and erroneous values. When human beings prioritize their desire to acquire material things from the natural resources of the earth without an ethical consideration for the wellbeing of other elements of the environment there is bound to be environmental degradation. Ayorinde and Olufemi (2003) opine that: "unrestrained human activities all over the world have contributed to environmental degradation and ecological crisis" (p. 66).

Environmental degradation results in the loss of species. The importance of species cannot be overstated. In the natural food chain, each organism depends on others. The death of one species certainly affects the other organisms. Human beings make use of food, medicine, furniture, and other materials that come from plants, animals, birds, fishes, the atmosphere, etc. The depletion and destruction of any of these negatively impact human beings. Every organism performs an environmental service in nature. Fishes and other aquatic animals depend on water. When the water is poisoned and polluted through mining activities like in places like Nigeria, Niger Delta, Equatorial Guinea, Democratic Republic of Congo, etc those fishes die or poison human beings when eaten.

Violence, war and terrorism are also major precipitators of environmental degradation. These are major causes of environmental degradation that are often not attended to or taken into serious consideration. The United Nations Conference on Environment and Development (1992) states that: "Warfare is inherently destructive of sustainable development. States shall therefore respect international law providing protection for the environment in times of armed conflict and cooperate in its further development, as necessary" (principle 24). Violence not only harms other human beings or social institutions but also the natural environment. Violence takes place on the land. Human beings who cause violence or go to war carry out their activities on the land and at times cross water bodies. Make-shift roads are made to give room for transport equipment and war machines to be moved to where they are needed. In the process trees, plants and other organisms are destroyed. As human beings fight and attack themselves forested land, grassland, and habitat of birds and other animals are destroyed. Places in Africa like Sierra Leone, Liberia, Nigeria, Ethiopia, Namibia, etc that have experienced violent conflicts have experienced the destruction of nature. Terrorism indiscriminately kills human beings and bomb the natural landscape. In the process, nature is degraded. Poisonous chemicals are used in war that damages the environment. Terrorists' attacks are not uncommon in Africa. Terrorist attacks have taken place in Nairobi, Kenya in 1998, Dar es Salaam in 1998, etc. There have been terrorist attacks in Niger, Mali, Burkina Faso, Nigeria, Cameroon, etc. Human lives and beautiful terrains are destroyed when there are violent or terrorist attacks. The built environment is also affected. Terrorists and those who fight wars steal and loot natural resources in the countries in which they are located to fund their violence and wars thus depleting the resources.

Related to urbanization is industrialization, the rapid emergence and growth of industries and factories. Industries always produce waste. Often these industries don't recycle or manage these wastes in a proper manner. In order to build more industries all over the continent trees are felled, the land is excavated and the atmosphere is polluted. No industry can be built without waste. What is needed is the proper management of that waste. Segynola (2007) notes that industries often discharge chemical effluents into land and water bodies around them thus degrading the quality of water and land; and there is also carbon monoxide, sulphur 
dioxide, smog and other related problems caused by industries. Writing concerning regions in Delta State in Nigeria, Segynola (2007) opines that the exploitation and transportation by oil and gas industries have damaged the soil, vegetal, aquatic resources through oil spillage and discharge of hot gases into the atmosphere; and agricultural land for farming and fishing have been damaged. Thus, people's source of livelihood has been gravely affected. What this author mentions concerning this region is common to all regions in Africa where there are mining activities. There is no region in Africa where there are mining activities that is free from environmental pollution and degradation.

Environmental degradation can be caused by climate change. Writing of the Horn of Africa, Mengisteab (2011) states that environmental degradation is caused by climate changes and human activities. Human activities for him alter land use patterns and land cover precipitating deforestation. The author just mentioned further notes that global deforestation comes partly from carbon dioxide emitted into the atmosphere. Mengisteab (2011) writes that:

Another factor that has exacerbated the degradation of the region's environment is appropriation of communal lands by the state. Oblivious to the land constraint and land-based communal conflicts their populations face, governments in the region have increasingly engaged in awarding land concessions to foreign investors, extinguishing the traditional land rights of their citizens. The governments of the region have been giving land concessions to corporations in extractive industries for decades. In recent years, however, they have also engaged in awarding land to foreign investors in large-scale commercial farming (par. 7).

Furthermore, Mengisteab (2011) states that:

Land takings have also contributed to the environmental degradation indirectly. They have exacerbated the land, pasture, and water constraints the peasants and nomads in the region face. Such constraints, of course, worsen the problems of overgrazing and over-farming. Since little compensation is given to those who are displaced, the land takings also contribute to the problems of unemployment, underemployment, and declining standards of living of communities, which, in turn, resort to unsustainable use of land and forest resources (par 11).

The causes and consequences of environmental degradation in Africa are innumerable. The ones given above suffice here. The fact is that environmental degradation has serious negative effects on natural values and resources. When the environment is degraded, the values that inhere and recognised in nature are equally degraded and depleted. To conserve the values in nature there is need to mitigate or eradicate environmental problems and degradation. Some of the ways to combat environmental degradation especially by conserving nature values are now presented below.

\section{Solutions to Environmental Degradation in Africa}

First and foremost, it is important to state that there must be environmental legislation and laws to protect the environment. This is a vital aspect of environmental governance. If there are no environmental legislations and regulations there will be environmental disorder on the part of human beings. In combating environmental degradation in the continent, the role and place of environmental laws and regulations should not be overlooked. Without environmental regulations, many persons will continue to simply act for selfish purposes. Environmental laws are necessary to restrain harmful behaviours towards the environment. Imagine if industries and factories are not regulated. Industries will just pollute the environment as they like. The environmental laws have to equally be enforced and implemented if not they are useless. Many countries in Africa have laws on mining activities. They cannot be held accountable and morally responsible when there are no environmental laws. Many human beings often will not follow and promote good order unless there are laws that impose the obligation on them. One of the vital reasons why government exists is to make and implement laws for the ordering and wellbeing of society. Without environmental laws, degradation and depletion of the values in nature will go unabated. Various African countries have environmental laws and agencies empowered to 
enforce those laws. Adewusi (2011) lists environmental protection legislation in Nigeria to include: (1) the 1979, Associated Gas Re-injection Act, (2) the 1971 Sea Fishery Act, (3) the 1971 Oils Terminal Dues Act, (4) the 1969 Petroleum Act, (5) the 1968 oil in Navigable Waters Act, and (6) the 1992 Environmental Impact Assessment Act. Environmental agencies in Nigeria include the Federal Ministry of Environment, the Federal Environmental Protection Agency, the National Environmental Standards Regulation and Enforcement Agency, etc. In South Africa, the South Africa Department of Environmental Affairs (2019) and their Acts and regulations are carried on their website. Pallangyo (2007) states that in Tanzania there is The Environmental Management Act, 20 of 2004. The fact is that different countries in Africa have their environmental laws and regulations. Laws and regulations, though not alone, are vital keys to mitigating environmental degradation in Africa.

Implementation and enforcement of environmental legislations and social reforms are equally necessary to abate environmental degradation. The role of the state in environmental conservation to mitigate environmental degradation can never be overemphasized. Various human rights instruments have laid out the roles of governments on this issue. United Nations Conference on Environment and Development (1992a) states that:

States shall cooperate in a spirit of global partnership to conserve, protect and restore the health and integrity of the Earth's ecosystem. In view of the different contributions to global environmental degradation, States have common but differentiated responsibilities. The developed countries acknowledge the responsibility that they bear in the international pursuit of sustainable development in view of the pressures their societies place on the global environment and of the technologies and financial resources they command (principle 7).

The Organisation of African Unity (1981), now the African Union, states that: "All peoples shall have the right to a general satisfactory environment favourable to their development" (art. 24). States are to protect and restore the integrity of the earth. States have no option but to implement policies and regulations to protect the environment. Agbese (2008) notes that in the 1970s and even the decades following it states in Africa often tend to trade economic development for environmental protection, and most often environmental regulations were not holistic as they ignored the full harms coming from environmental degradation. Many African states have ignored the issues of environmental degradation and even when it is mentioned environmental laws are ignored or sabotaged. Agbese (2008) notes that environmental enforcement officers are corrupt, simply implement "colonial conservation policies and not attending to issues of social justice, reliance on foreign business companies who have their own agenda." In a place like Nigeria, foreign multinational companies prefer to pay than stop gas flaring that is polluting the environment. States must implement environmental regulations to protect the environment. The United Nations Conference on Environment and Development (1992a) states thus: "States shall enact effective environmental legislation. Environmental standards, management objectives and priorities should reflect the environmental and developmental context to which they apply. Standards applied by some countries may be inappropriate and of unwarranted economic and social cost to other countries, in particular developing countries" (principle 11).

There is need for vibrant and dynamic environmental non-governmental movements to hold governments accountable. Many African states have fragile and weak environmental groups. Agbese (2008) writes that: "As a result of the absence of well-organized environmental protection movements, African governments paid little or no attention to major environmental issues such as desertification, resource depletion, pollution caused by industrial emission and the extensive pollution resulting from the extraction of petroleum and other minerals. Instead, environmental issues were relegated to the background" (p. 186).

Developing environmental consciousness and promoting environmental awareness and education is also important to conserving environmental values and thus abating environmental degradation. United Nations Education, Scientific, and Cultural Organization, UNESCO (1977) enunciates that environmental education should help the individual 
to acquire values, knowledge, attitudes, and skills necessary to pre-empt and solve environmental problems and effective environmental management. UNESCO also states that it should create a spirit of responsibility and solidarity among individuals and countries to foster conservation and environmental improvement. United Nations Conference on Environment and Development (1992b) states that:

Education, including formal education, public awareness and training should be recognized as a process by which human beings and societies can reach their fullest potential. Education is critical for promoting sustainable development and improving the capacity of the people to address environment and development issues. While basic education provides the underpinning for any environmental and development education, the latter needs to be incorporated as an essential part of learning. Both formal and non-formal education are indispensable to changing people's attitudes so that they have the capacity to assess and address their sustainable development concerns. It is also critical for achieving environmental and ethical awareness, values and attitudes, skills and behaviour consistent with sustainable development and for effective public participation in decision-making. To be effective, environment and development education should deal with the dynamics of both the physical/biological and socio-economic environment and human (which may include spiritual) development, should be integrated in all disciplines, and should employ formal and non-formal methods and effective means of communication. (Agenda 21, chapter 36).

It is important to state the value of environmental education in mitigating environmental degradation in Africa. Rim-Rukeh (2009) states that: "the knowledge of environmental education will promote worldwide public awareness of environmental problems and issues and support for environmental protection" (p. 45). As long as human beings remain on earth and carry out human activities environmental problems will not totally go away. This is why it is important for citizens to be educated in environmental knowledge to help them contribute to ameliorating these environmental problems. Various states in Africa such as Nigeria,
South Africa, etc have programmes or curriculum for environmental education.

There is also need for environmental remediation and restoration. If the land has been deforested there is need to plant more trees and forest to restore the viability and fertile of the land. Trees can also be planted to stop desertification. With regard to the environment of Ogoniland in Nigeria's Niger Delta, the United Nations Development Programme says it will take up to 25 years to remediate the environment. The point here is that there is a place for environmental remediation.

Human overpopulation endangers the sustainable state of the environment in Africa. The more people you have on the earth the more human activities that take place. There will be more houses for residential purposes and more industries have to be created to meet human needs. Hook (2008) writes that: "One of the main problems is that in many parts of the world humankind's population is simply too high, leaving nowhere for fauna and flora to exist. As a result, those species that cannot adapt either die out of their numbers become dramatically reduced" (p. 55). Africa is overpopulated. The more people, the more pressure on the earth's resources. The United Nations Conference on Human Environment (1972) states that: "The natural growth of population continuously presents problems for the preservation of the environment, and adequate policies and measures should be adopted, as appropriate, to face these problems. Of all things in the world, people are the most precious. It is the people that propel social progress, create social wealth, develop science and technology and, through their hard work, continuously transform the human environment. Along with social progress and the advance of production, science and technology, the capability of man to improve the environment increases with each passing day" (no 5). The debate on the appropriate means is debatable. That debate will not be entered into here as it is not the focus of this paper. But it is imperative to state that there is need to control the population through morally sound means that are respectful of human personhood and dignity

Environmental degradation caused by human beings is immoral. It can even amount to a crime if it deprives other human beings of their rights to 
survival and existence. His is where the place of ethics comes to play. There is also the moral question of environmental integrity. There is a moral imperative for human beings to live in harmony with nature. The United Nations Conference on Environment and Development (1992) enunciates thus: "Human beings are at the centre of concerns for sustainable development. They are entitled to a healthy and productive life in harmony with nature" (principle 1). Though human beings have a right to a productive and healthy life, it has to be done in harmony with nature. This is where the principles of conservation come to play. The human stay on earth should be benign, not malign. It should also foster the good of nature. Very often the human presence on earth has been disruptive and harmful to the environment. Living in harmony with nature is for the good of humanity and nature. When human beings harm, disrupt and degrade nature they provoke environmental health challenges thus harming human wellbeing and health. Human life itself is negatively affected. There is a moral obligation to stop environmental degradation. It is a moral obligation because it is the right thing to do. Even if someone was to conceive that there are no direct duties to nature at least there are indirect duties to nature as protecting nature invariably fosters human wellbeing.

There is need for moral conversion of human hearts. Many forms of environmental degradation are caused by human beings. It is human beings who equally have a responsibility to act to end environmental degradation. Environmental awareness and consciousness of the human responsibility to mitigate environmental degradation are crucial and very important. Tella (2015) rightly avers that: "humanity should be driven by a vision of environmental sustainability that improves life for everyone without degrading nature's economy that sustains us all. There is, therefore, the need for supportive, integrated and coordinated approaches for the management of natural resources and environmental protection." ( $p$. $\mathrm{xv})$. The United Nations Conference on Environment and Development (1992a) states that: "Peace, development and environmental protection are interdependent and indivisible" (principle 25).

The emphasis on unlimited economic growth is unethical. It is true that human beings must develop and have a right to use the things of nature to sustain themselves like other organisms. Development must be restrained by the ethics of sustainability. It is widely acknowledged today that nature does not have unlimited capacity and that is why today there is a distinction between renewable and nonrenewable resources. Non-renewable resources can easily be depleted unless wisely used. Even renewable resources have to be wisely used and renewed.

The argument of this paper is that natural values should be conserved to mitigate environmental degradation in Africa. All values that are found in nature have been loosely named natural values in this paper. The value is there before it was recognized by human beings. It will be wrong to assert that there is value in nature because we perceive the value. But this paper which to categorically state that environmental pragmatism requires that no matter your position in this debate it is important to conserve the values inherent or that human beings have perceived in nature. This is important for human wellbeing and to save the planet. Values perceived in nature; especially intrinsic value should be protected. Holmes (1988) argues that: "Duties arise...seldom be true. (p 188). Even if someone does not agree to finding intrinsic value in the earth, enlightened selfish interests of humans still require environmental protection. Wilson (2006) affirms that: "it follows that human self-interest is best served by not overly harming the other life forms on Earth that still survive" for humans need to earth to survive (p. 27). Wilson (2006) argues persuasively further saying:

Even if the rest of life is counted of no value beyond the satisfaction of human bodily needs, the obliteration of nature is a dangerous strategy. For one thing, we have become a species specialized to eat the seeds of four kinds of grass wheat, rice, corn and millet. If these fail, from disease or climate change, we too shall fail. Some fifty thousand wild plant species (many of which face extinction) offer alternative food sources. If one insists on being thoroughly practical about the matter, allowing these and the rest of wild species to exist should be considered part of a portfolio of long-term investment. Even the most recalcitrant people must come to view conservation as simple 
prudence in the management of earth's natural economy. Yet few have begun to think that way at all. (p. 11)

\section{CONCLUSION}

The paper has shown clearly above that environmental degradation is a grave problem afflicting the African continent. It has many negative and disastrous consequences that have been stated above. The negative impact affects both human beings and other life forms on planet earth. It was clearly shown that human beings have a responsibility to work to abate and even eradicate environmental degradation. If environmental degradation is not abated it will impede flourishing on earth. It is important to recognise that the earth has intrinsic value. Human beings should not simply act for their own well-being. They should act for the wellbeing and welfare of the entire earth and her life-forms. It is proposed here that with that recognition and consequent conservation life on earth will be preserved.

\section{REFERENCES}

Adam, H. M. (2001). Somalia: Environmental degradation and environmental racism. In $\mathrm{L}$ Westra \& Lawson B. E. (Ed.), Faces of environmental racism: Confronting issues of global justice (pp. 203-227). Lanham: Rowman \& Littlefield Publishers.

Adekunle V. A. J., Okoko E., and Adeduntan S. A. (Ed.), Challenges of environmental sustainability in a democratic government (pp. 9-13). Lagos: Environment and Behaviour Association of Nigeria.

Adewusi, P. A. K. (2011). The environment: Law and management in Nigeria. Lagos: Hybrid Consult.

Agbese, P. O. (2008). The state and environment in Africa. In G. K. Kieh, and P. O. Agbese (Ed.), The state in Africa; Issues and perspectives (pp. 185-207). Ibadan: Kraft Books Limited.

Ayorinde, A. A., and Olufemi, O. E. (2003). The role of Urban and regional planning in controlling environmental degradation in Nigeria. In Victor Adekunle, Enos Okoko, and
Sunday Adeduntan (Ed.), Challenges of environmental sustainability in a democratic government (pp. 65-72). Lagos: Environment and Bahaviour Association of Nigeria.

Bellamy, P. (2007). Academic's dictionary of environment. New Delhi: Academic (India) Publishers.

Chukwuka K. S. \& Jimoh, W. A. (2018). The impacts of petroleum production on terrestrial fauna and flora in the Oil-Producing Region of Nigeria. Retrieved January 20, 2020, from https://www.sciencedirect.com/topics/earth and -planetary-sciences/environmental- degradation

El-Haggar, S. M. (2007). Sustainable Development and environmental reform. Retrieved January 20, 2020. from https://www.sciencedirect.com/ science/article/pii/B978012373623950006X?vi a\%3Dihub\#!

General Multilingual Environmental Thesaurus. (2020). Environmental degradation. Retrieved January 20, 2020, from https://www.eionet.eur opa.eu/gemet/en/concept/15154

Holmes, R. (1988). Environmental Ethics: Duties to and values in the natural world. Philadelphia: Temple University Press.

Hook, P. (2004). The little book of environmental principles. London: New Holland Publishers (UK) Limited.

Mabogunje, A. L. (1998). The environmental challenges in Sub Saharan Africa. African Technology Forum, 8 (1). Retrieved January 20, 2020, from http://web.mit.edu/africantech/ww w/articles/EnvChall.htm

Meadows et al. (1972). The limits of growth: A report for the Club of Rome's project on the predicament of mankind. Retrieved January 15 , 2020, from http://www.donellameadows.org/w p-content/userfiles/Limits-to-Growth-digitalscan-version.pdf

Meadows, D. et al. A Synopsis: Limits to Growth: The 30- Year Update http://donellameadows.or g/archives/a-synopsis-limits-to-growth-the-30year-update/ 
Mengisteab, K. (2011). Environmental degradation in the Greater Horn of Africa: Some impacts and future implications. Retrieved January 20, 2020, from https://www.twn.my/title2/resurgence/201 1/251-252/cover02.htm

Micheals, F. (2004). Lotus illustrated dictionary of environmental studies. Daryaganj, New Delhi: Lotus Press.

Nakweya, G. (2019). Environmental degradation threat to health, UN says. Retrieved January 20, 2020, from https://www.scidev.net/sub-saharanafrica/biodiversity/news/environmentaldegradation-threat-to-health.

Ndimele, P. E., \& Erondu, E. S. (2018). Remediation of crude oil spillage. Retrieved January 20, 2020, rom https://www.sciencedire ct.com/topics/earth-and-planetary-

sciences/environmental-degradation

Omaka, A. (2018). Nigerian conservation law and international environmental treaties. Lagos: Princeton and Associates Publishing Company Limited.

Omisore, E. O., \& Akande, C. G. (2003). The roles of all tiers of government and non-governmental organizations (NGOs) in environmental conservation.

Organisation of Africa. (1981). African (Banjul) Charter on Human and Peoples' Rights. Retrieved January 20, 2020, from file:///C:/Users/ADMIN/Downloads/banjul_cha rter.pdf

Pallangyo, D. M. (2007). Environmental law in Tanzania; How far have We gone? Law, Environment and Development Journal, 3 (1): 26. Retrieved January 2020, from available at http://www.lead-journal.org/content/07026.pdf

Pinchot, G. (2009). Principles in conservation. In Thomas Easton (Ed.), Environmental Studies (pp. 8-9). Boston: McGraw Hill Higher Education.

Rim-Rukeh, A. (2009). Environmental Science: An introduction. Ibadan: Kraft Books Limited.
Segynola, A. A. (2001). Environmental impact of industrialization in Nigeria. In G.E.K. Ofomata and P. O. Phil-Eze (Ed.), Geographic perspectives on environmental problems and management in Nigeria (pp. 182-195). Enugu: Jamoe Publishers.

Shrinkhal, R. (2019). Economics, technology, and environmental protection. Retrieved January 19, 2020, from https://www.sciencedirect.com/topi cs/earth-and-planetary-sciences/environmentaldegradation

South Africa Department of Environmental Affairs. (2019). Acts and Regulations. Retrieved January 10, 2020, from https://www.environment.gov.z a/legislation/actsregulations

Stremlau, N. (2019). Governance without government in the Somali territories. Journal of International Affairs. Retrieved January 19, 2020, from https://jia.sipa.columbia.edu/governancewithout-government-somali-territories

Tella, A. (2015). Critical issues in environmental sustainability. Abeokuta: Center for Human Security Olusegun Obasanjo Presidential Library.

United Nations Conference on Environment and Development. (1992a). Rio Declaration on Environment and Development. Retrieved January 20, 2020, from https://www.cbd.int/do c/ref/rio- declaration.shtml

United Nations Conference on Environment and Development. (1992b). Agenda 21. Retrieved January 20, 2020. From https://sustainabledevelopment.un.org/content/d ocuments/Agenda21.pdf

United Nations Conference on Human Environment. (1972). Declaration of the United Nations Conference on the Human Environment. Retrieved January 20, 2020, from file:///C:/Users/ADMIN/Downloads/6471.pdf

United Nations Education, Scientific, and Cultural Organization (UNESCO. (1977). Tbilisi Declaration. Retrieved January 20, 2020, from http://www.gdrc.org/uem/ee/tbilisi.html 
East African Journal of Environment and Natural Resources, Volume 3, Issue 1, 2021

Article DOI: https://doi.org/10.37284/eajenr.3.1.371

Wilson, E. O. (2006). The creation: An appeal to save life on Earth. New York: W. W. Norton and Company.

90 This work is licensed under a Creative Commons Attribution 4.0 International License. 